\title{
STUDI KECEPATAN PUTARAN MOTOR COMPRESSOR AIR CONDITIONER INVERTER TERHADAP PERUBAHAAN SUHU RUANGAN
}

\author{
Afrizal Jaya Saputra ${ }^{1}$, Atmam ${ }^{2}$, Zulfahri ${ }^{3}$ \\ 1,2,3 Program Studi Teknik Elektro, Fakultas Teknik, Universitas Lancang Kuning Pekanbaru. \\ Jl. Yos Sudarso km. 8 Rumbai, Pekanbaru, Telp. (0761) 52324 \\ Email: afrizaljaya21@gmail.com ${ }^{1}$, atmam@unilak.ac.id ${ }^{2}$, zulfahri@unilak.ac.id ${ }^{3}$
}

\begin{abstract}
ABSTRAK
Perubahan beban kalor sesaat yang dihasilkan oleh panas dari luar ruangan akan membuat kapasitas dari beban pendinginan air conditioner inverter juga berubah. Semakin tinggi suhu panas dari luar dan dari dalam ruangan maka kapasitas pendinginan dari air conditioner inverter juga semakin tinggi dan juga menyebabkan putaran motor compressor berubah. Untuk itu diperlukan penelitian tentang perubahan kecepatan motor compressor akibat perubahan suhu dari dalam maupun dari luar ruangan. Dari analisa diperoleh beban pendinginan air conditioner yang dibutuhkan untuk ruangan show room sebesar 7,6 PK, dengan energi 69172,47 BTU pada saat suhu diluar ruangan $38,9^{\circ} \mathrm{C}$. Putaran minimal motor compressor adalah $1560 \mathrm{rpm}$, dengan frekuensi input motor compressor $52 \mathrm{~Hz}$ dan tegangan sebesar 80 Volt. Putaran maksimal motor compressor $7620 \mathrm{rpm}$, dengan frekuensi input $255 \mathrm{~Hz}$ dan tegangan sebesar 402 Volt. Perubahan suhu didalam ruangan membuat kecepatan motor compressor menjadi turun, seperti pada suhu $25,2^{\circ} \mathrm{C}$ kecepatan motor compressor $7620 \mathrm{rpm}$ sementara pada suhu $24,9^{\circ} \mathrm{C}$ kecepatan motor compressor $4200 \mathrm{rpm}$ sedangkan pada suhu $24,1^{\circ} \mathrm{C}$ kecepatan motor compressor adalah $3180 \mathrm{rpm}$.
\end{abstract}

Kata kunci : Suhu, frekuensi, motor compressor dan penghematan energi.

\begin{abstract}
The instantaneous changes in caloric load generated by heat from outside the room will make the capacity of the cooling load of the inverter air conditioner also change. The higher value of heat temperature from the outside and from the room will make the cooling capacity of the inverter air conditioner is higher and also causes the motor rotation of the compressor to change. Therefore we need research about change of motor speed compressor due to temperature change from inside and outside of the room. From the analysis obtained cooling load of air conditioner needed for show room equal to 7,6 PK, with energy 69172,47 BTU when temperature of outside is $38,9^{\circ} \mathrm{C}$. The minimum rotation of the compressor is $1560 \mathrm{rpm}$, with $52 \mathrm{~Hz}$ an input compressor frequency and 80 Volts voltage. The maximum rotation of compressor is $7620 \mathrm{rpm}$, with $255 \mathrm{~Hz}$ input frequency and 402 Volt voltage. Temperature changes in the room make the compressor speed decrease, as at $25.2{ }^{\circ} \mathrm{C}$ compressor speed $7620 \mathrm{rpm}$, at $24.9^{\circ} \mathrm{C}$ the speed of the compressor $4200 \mathrm{rpm}$ while at $24.1{ }^{\circ} \mathrm{C}$ the speed of the compressor is $3180 \mathrm{rpm}$. The energy savings between $\mathrm{AC}$ inverter and without inverter is $1815 \mathrm{Wh}$.
\end{abstract}

Keywords: Temperature, frequency, compressor motor and energy saving.

\section{PENDAHULUAN}

Perubahan beban kalor sesaat yang di hasilkan oleh panas dari luar ruangan akan membuat kapasitas dari beban pendinginan (Air Conditioner) $A C$ inverter juga ikut berubah. Semakin tinggi suhu panas dari luar ruangan maka kapasitas pendinginan dari AC inverter juga akan semakin tinggi. Sebaliknya jika pengaruh beban kalor dari luar kecil maka kapasitas beban pendinginan $A C$ inverter pun akan menjadi kecil.
Perubahan kapasitas pendinginan tersebut dideteksi oleh sensor suhu dari unit $A C$ inverter yang memberikan signal kepada module inverter. Module inverter akan memberikan output tegangan dan frekuensi ke compressor yang berubah-ubah disesuaikan dengan kebutuhan beban pendinginan ruangan. Pada saat suhu sudah tercapai, maka module inverter akan memberikan penyesuaian kapasitas pendinginan yang di hasilkan oleh unit $A C$ inverter. 
Kelemahan pada sistem ini adalah compressor harus tetap bekerja pada saat beban puncak full load walaupun pada saat $A C$ tidak sedang mengalami perubahan atau variasi beban pendinginan dan suhu yang di inginkan tidak dapat dipertahankan. Semakin sering terjadinya fluktuasi akibat beban pendinginan, maka akan semakin kecil kemampuan compressor untuk menghemat energi [1-9]. Untuk itu diperlukan penelitian tentang perubahan kecepatan motor compressor yang disebabkan oleh suhu dan mengetahui seberapa besar tegangan dan frekuensi yang masuk ke compressor pada saat suhu dalam ruangan telah tercapai sesuai dengan pengaturan suhu referensi yaitu $24^{\circ} \mathrm{C}$.

\section{METODE PENELITIAN}

\subsection{Data Pengukuran Ruangan}

Untuk menghitung beban kalor pada ruangan, diperlukan data-data ukuran dimensi pada ruangan yang akan dilakukan penelitian. Pengambilan data dilakukan langsung untuk mengetahui berapa panjang, lebar dan tinggi ruangan. Bagian-bagian bahan bangunan seperti tebal dinding, tebal kaca dan data peralatan listrik yang ada mengeluarkan kalor juga harus diambil datanya.

\subsubsection{Daerah Luas Bangunan}

Ruangan dealer Daikin digambarkan dengan menggunakan autocad. Pada Gambar 3.1 Tampak dari atas. Sisi selatan pada bangunan adalah dinding kaca. Pada daerah dinding kaca, sinar matahari akan tembus masuk keruangan. Panas dari luar ruangan akan sangat cepat terpindah ke dalam. Efeknya adalah beban panas dari ruangan akan semakin tinggi bila dibandingkan dengan ruangan yang semua sisi beton semen. Untuk itu perlu dilakukan perhitungan beban pendinginan yang sesuai dengan kapasitas beban kalor ruangan.

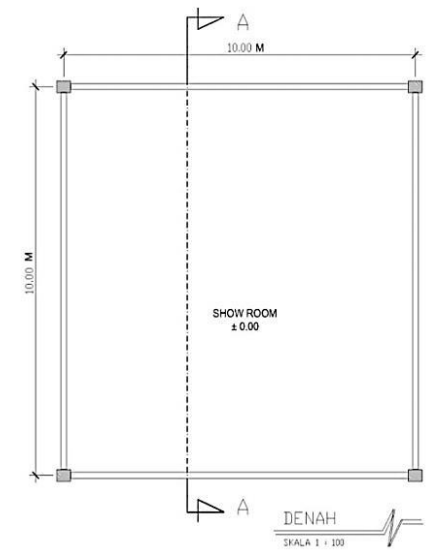

Gambar 1. Gambar ruangan tampak atas

Ruangan dealer Daikin seperti pada Gambar 2 merupakan bangunan tampak dari samping.

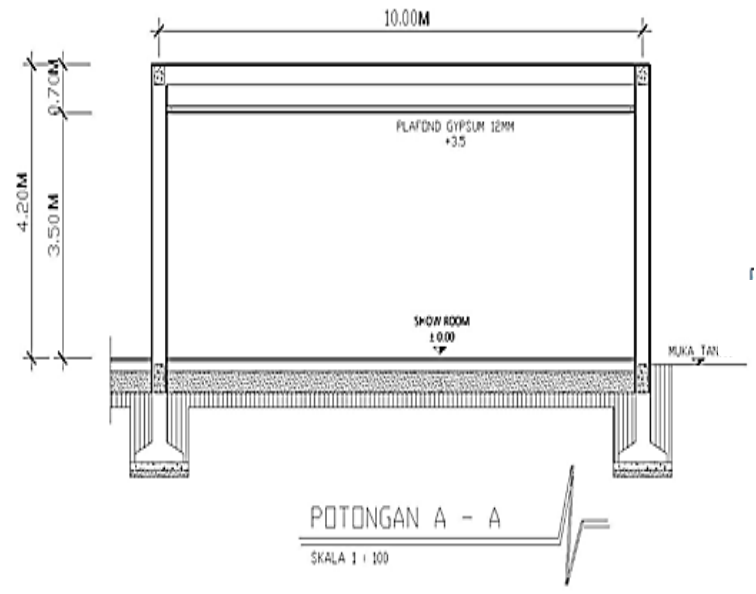

Gambar 2 Gambar ruangan tampak samping

Keterangan :

Panjang ruangan $\quad=10$ meter

Lebar ruangan $\quad=10$ meter

Tinggi ruangan $\quad=3.5$ meter

\subsection{Rumus frekuensi dan arus compressor}

Frekuensi motor $A C$ dapat dihitung dengan persamaan 1 [10].

$n=\frac{120 . \mathrm{f}}{\mathrm{P}}$

Keterangan :

$\mathrm{n}=$ Jumlah putaran motor permenit /rpm

$\mathrm{P}=$ Jumlah kutup motor

$\mathrm{F}=$ Frekuensi $(\mathrm{Hz})$

Arus motor tiga phasa dapat dihitung dengan persamaan 2 [11-13].

$P=\sqrt{3} \times V \times I \times \cos \varphi \quad(3$ phasa $)$

Keterangan :

$\mathrm{V}=$ tegangan

$\mathrm{I}=$ arus motor

\subsection{Hasil Rekaman Data Suhu diluar Ruangan.}

Data rekaman suhu diluar ruangan diukur menggunakan alat Tasco Temperatur. Dibawah ini adalah grafik hasil rekaman.

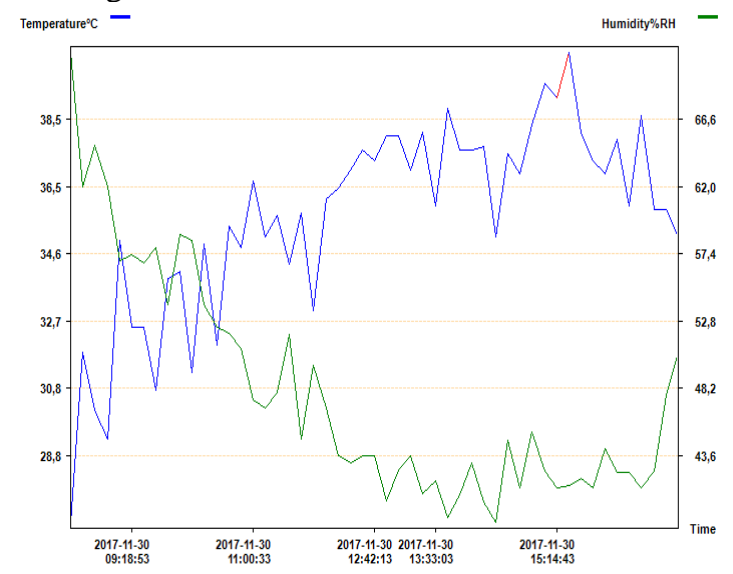

Gambar 3. Hasil Record Suhu diluar Ruangan 
Nilai suhu tertinggi adalah $38,9^{\circ} \mathrm{C}$, nilai suhu rata-rata $34^{\circ} \mathrm{C}$ dan nilai suhu terendah $26^{\circ} \mathrm{C}$. Grafik diatas diambil dari hasil rekaman Tasco Temperatur Tools yang diukur mulai pada waktu 08:00 sampai 16:45 WIB. Pengukuran suhu pada jam tersebut dilakukan karna bertepatan dengan waktu operasional kantor.

\subsection{Langkah- langkah Penelitian}

Adapun langkah-langkah yang dilaksanakan dalam penelitian ini, seperti pada Gambar 4.

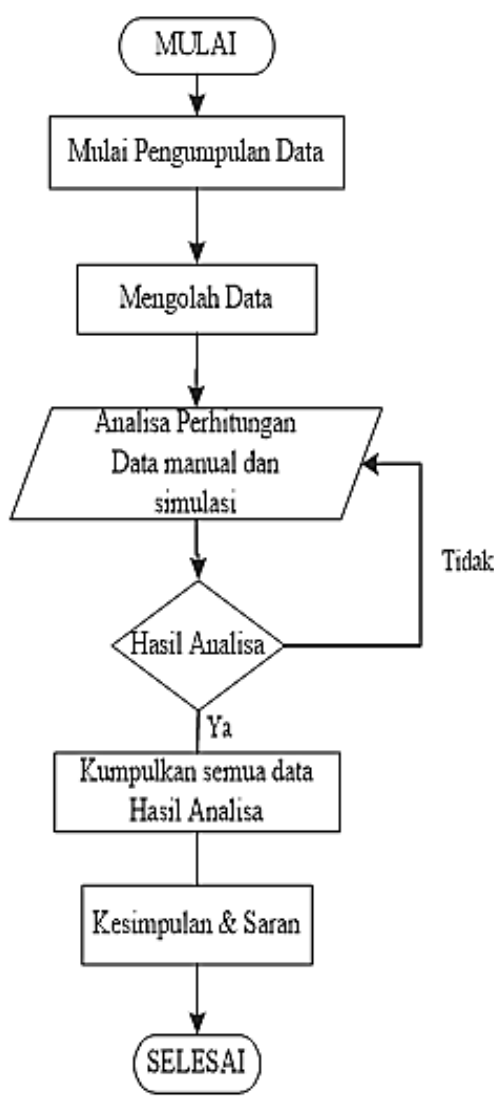

Gambar 4. Flowchart Pelaksanaan Penelitian

\section{HASIL DAN PEMBAHASAN}

\subsection{Hasil Penjumlahan Beban Kalor}

Penjumlahan beban kalor dari dalam dan efek dari luar ruangan, sesuai dengan perubahan suhu diluar ruangan seperti Tabel 1 pada suhu dalam 24 ${ }^{\circ} \mathrm{C}$ dan luar ruangan $26{ }^{\circ} \mathrm{C}$. Kebutuhan pendinginan ruangan sebesar $49145 B T U$, dan kapasitas compressor sebesaar 5,4 $P K$. Pada suhu rata-rata diluar $34^{\circ} \mathrm{C}$, kapasitas compressor naik sebesar 7,3 $P K$. Pada suhu tertinggi diluar $38,9^{\circ} \mathrm{C}$, kapasitas pendingin semakin naik sebesar 69172,4734 BTU. dengan kapasitas compressor sebesar 7,6 PK. Semakin tinggi jarak antara suhu dalam dan luar ruangan, maka semakin tinggi kebutuhan kalor yang di butuhkan dan semakin tinggi juga kapasitas pendinginannya. Hasil perhitungan tersebut diperoleh pada tabel 1 .

Tabel 1. Hasil Perhitungan Manual Beban Pendinginan Ruangan

\begin{tabular}{|c|c|c|c|}
\hline Beban kalor & $\begin{array}{l}\text { Suhu minimal } \\
\qquad 26^{\circ} \mathrm{C}\end{array}$ & $\begin{array}{c}\text { Suhu rata-rata } \\
34^{\circ} \mathrm{C}\end{array}$ & $\begin{array}{c}\text { Suhu maksimal } \\
38,9^{\circ} \mathrm{C}\end{array}$ \\
\hline $\begin{array}{c}\text { Radiasi } \\
\text { matahari ke } \\
\text { dinding kaca }\end{array}$ & $9393 \mathrm{kcal} / \mathrm{h}$ & $9393 \mathrm{kcal} / \mathrm{h}$ & $9393 \mathrm{kcal} / \mathrm{h}$ \\
\hline $\begin{array}{c}\text { Transmisi } \\
\text { kalor melalui } \\
\text { dinding beton }\end{array}$ & $385 \mathrm{kcal} / \mathrm{h}$ & $1925 \mathrm{kcal} / \mathrm{h}$ & $2868,25 \mathrm{kcal} / \mathrm{h}$ \\
\hline $\begin{array}{c}\text { Panas } \\
\text { infiltrasi }\end{array}$ & $129,6 \mathrm{kcal} / \mathrm{h}$ & $648 \mathrm{kcal} / \mathrm{h}$ & $965,52 \mathrm{kcal} / \mathrm{h}$ \\
\hline $\begin{array}{c}\text { Transmisi } \\
\text { partisi lantai }\end{array}$ & $309,8 \mathrm{kcal} / \mathrm{h}$ & $1540 \mathrm{kcal} / \mathrm{h}$ & $2294,6 \mathrm{kcal} / \mathrm{h}$ \\
\hline $\begin{array}{c}\text { Kalor } \\
\text { manusia }\end{array}$ & $212 \mathrm{kcal} / \mathrm{h}$ & $212 \mathrm{kcal} / \mathrm{h}$ & $212 \mathrm{kcal} / \mathrm{h}$ \\
\hline $\begin{array}{c}\text { Peralatan } \\
\text { listrik } \\
\text { didalam }\end{array}$ & $1312 \mathrm{kcal} / \mathrm{h}$ & $1312 \mathrm{kcal} / \mathrm{h}$ & $1312 \mathrm{kcal} / \mathrm{h}$ \\
\hline Lampu & $396 \mathrm{kcal} / \mathrm{h}$ & $396 \mathrm{kcal} / \mathrm{h}$ & $396 \mathrm{kcal} / \mathrm{h}$ \\
\hline $\begin{array}{l}\text { Total beban } \\
\text { kalor }\end{array}$ & $12385,48 \mathrm{kcal} / \mathrm{h}$ & $16666 \mathrm{kcal} / \mathrm{h}$ & $17441,37 \mathrm{kcal} / \mathrm{h}$ \\
\hline Energy & 49145,5 BTU & 66130 BTU & 69172,4734 BTU \\
\hline $\begin{array}{c}\text { Peak kreak / } \\
\mathrm{Hp}\end{array}$ & 5,4 PK & 7,3PK & $7,6 P K$ \\
\hline
\end{tabular}

Air conditioner $V R V$ akan menyesuaikan beban pendinginan dengan cara merubah kecepatan putar motor compressor. Pada awal mula bekerja, compressor akan berputar dari kecepatan rendah sampai dengan kecepatan maksimal. Untuk dapat mengejar suhu referensi didalam ruangan. Setelah mendekati suhu referensi pada ruangan, microcontroller akan menyesuaikan putaran compressor sesuai dengan kapasitas beban pendinginan. Dengan cara merubah tegangan dan frekuensi yang masuk kecompressor. Untuk membuktikan hasil hitungan manual, maka harus dilakukan simulasi.

\subsection{Hasil Simulasi Checker}

Data hasil simulasi checker diambil untuk bahan penelitian. Pengukuran kecepatan motor pada saat suhu dalam dan luar ruangan terjadi perubahan. Dari hasil simulasi checker, suhu ruangan yang sudah tercapai akan membuat putaran motor yang awalnya tinggi menjadi rendah dan pada saat terjadinya perubahan suhu yang tinggi diluar ruangan, akan membuat kecepatan motor compressor menjadi naik.

\subsubsection{Pengukuran Kecepatan Compressor}

Awal mula beroperasi, compressor akan bekerja pada kecepatan minimal sampai kecepatan maksimal untuk mencapai suhu ruangan yang di referensikan yaitu $24{ }^{\circ} \mathrm{C}$. Berikut hasil simulasi dari checker pada Gambar 5. 


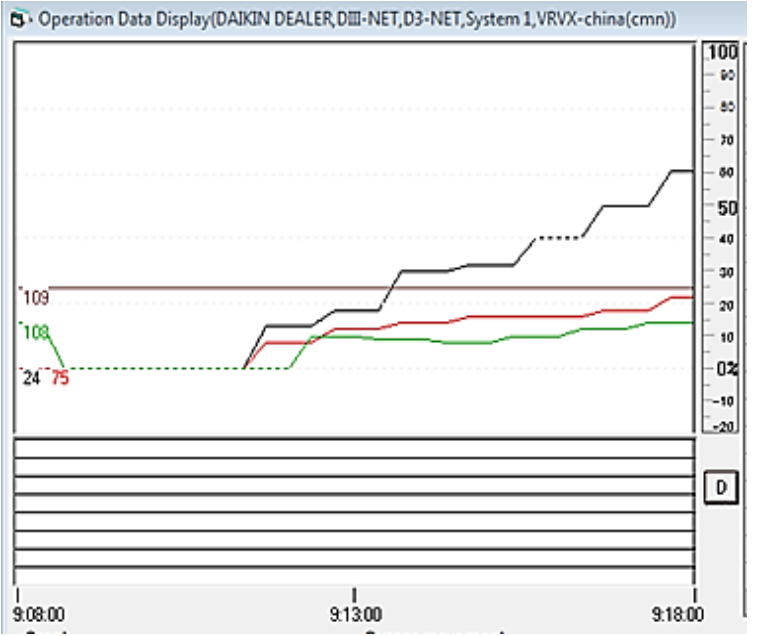

Gambar 5 Hasil Simulasi Checker Grafik Suhu dan Kecepatan Motor Compresor.

Karena hasil grafik dari simulasi checker tidak bisa langsung di simpan, maka data hasil simulasi checker dipindahkan ke dalam program microsoft excel. Dengan cara mengambil data checker dari file tersimpan lalu buat data tabel di excel untuk membuat grafik tersebut. Grafik hasil simulasi checker seperti pada Gambar 6.

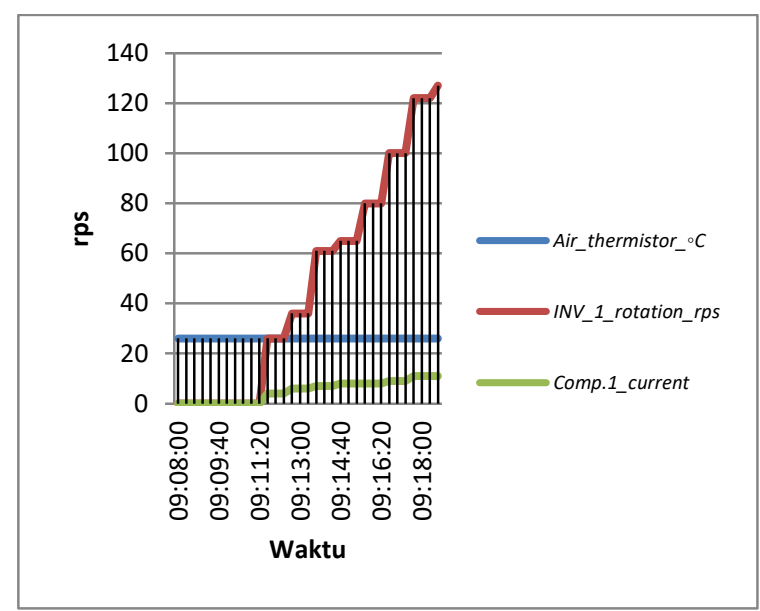

Gambar 6. Grafik Compressor Running Dengan kecepatan 0 - 127 rps.

Compressor inverter mulai bergerak perlahan dari kecepatan 0 - 127 rps, yang berguna untuk menurunkan arus start yang tinggi bila dibandingkan dengan motor noninverter. Compressor akan terus berputar maksimal hingga suhu dalam ruangan tercapai sesuai dengan suhu referensinya. Nilai suhu, kecepatan compressor dan arus seperti pada Tabel 2.
Tabel 2 Hasil Pengukuran dengan Menggunakan

\begin{tabular}{cccc}
\multicolumn{3}{c}{ checker } \\
Jam & $\begin{array}{c}\text { Suhu } \\
\text { dalam } \\
\text { ruangan } \\
\left({ }^{\circ} \text { C) }\right.\end{array}$ & $\begin{array}{c}\text { Putaran } \\
\text { compressor } \\
(\text { rps })\end{array}$ & $\begin{array}{c}\text { Arus } \\
\text { compressor } \\
\text { (Amp) }\end{array}$ \\
\hline 09:08:00 & 26 & 0 & 0 \\
09:08:20 & 26 & 0 & 0 \\
09:08:40 & 26 & 0 & 0 \\
09:11:40 & 26 & 26 & 4 \\
09:12:00 & 26 & 26 & 4 \\
09:12:20 & 26 & 26 & 4 \\
09:12:40 & 26 & 36 & 6 \\
09:13:20 & 26 & 36 & 6 \\
09:13:40 & 26 & 61 & 7 \\
09:14:00 & 26 & 61 & 7 \\
09:14:20 & 26 & 61 & 7 \\
09:14:40 & 26 & 65 & 8 \\
09:15:00 & 26 & 65 & 8 \\
09:15:20 & 26 & 65 & 8 \\
09:15:40 & 26 & 80 & 8 \\
09:16:00 & 26 & 80 & 8 \\
$09: 16: 20$ & 26 & 80 & 8 \\
$09: 16: 40$ & 26 & 100 & 9 \\
$09: 17: 00$ & 26 & 100 & 9 \\
$09: 17: 20$ & 26 & 100 & 9 \\
$09: 17: 40$ & 26 & 122 & 11 \\
$09: 18: 00$ & 26 & 122 & 11 \\
09:18:20 & 26 & 122 & 11 \\
$09: 18: 40$ & 26 & 127 & 12 \\
\hline & & &
\end{tabular}

Dari Grafik 6 dan Tabel 2, kecepatan compressor yang berubah dari 0 sampai kecepataan $127 \mathrm{rps} / 7620 \mathrm{rpm}$ pada suhu dalam ruangan $26^{\circ} \mathrm{C}$ dan arus 12Amper. Pada saat itu compressor sudah dalam kondisi kecepatan maksimal dengan kapasitas 7,6 PK. Untuk mengetahui Frekuensi dan tegangan input pada compressor, dari hasil pengukuran manual dengan melihat saat arus kerja yang sama yaitu :

a. Pada arus 4 Amper, frekuensi dan tegangan input compressor adalah $52 \mathrm{~Hz}$ dan 80 Volt.

b. Pada arus 6 Amper, frekuensi dan tegangan input compressor adalah $72 \mathrm{~Hz}$ dan 110 Volt.

c. Pada arus 7 Amper, frekuensi dan tegangan input compressor adalah $122 \mathrm{~Hz}$ dan 180 Volt.

d. Pada arus 8 Amper, frekuensi dan tegangan input compressor adalah $123 \mathrm{~Hz}-130 \mathrm{~Hz}$ dan 200 Volt - 282 Volt.

e. Pada arus 9 Amper, frekuensi dan tegangan input compressor adalah $140 \mathrm{~Hz}-192 \mathrm{~Hz}$ dan 301 Volt - 361 Volt.

f. Pada arus 10 Amper, frekuensi dan tegangan input compressor adalah $200 \mathrm{~Hz}-220 \mathrm{~Hz}$ dan 371 Volt - 389 Volt.

g. Pada arus 11 Amper dan 12 Amper, frekuensi dan tegangan input compressor adalah $224 \mathrm{~Hz}-$ $255 \mathrm{~Hz}$ dan 389 Volt - 402 Volt.

Untuk mengetahui kebenaran dari hasil 
pengukuran manual, maka perhitungan dilakukan dengan menggunakan persamaan 1 dan 2 .

Pada arus 12 Amper, kecepatan pada compresor adalah $127 \mathrm{rps}=7620 \mathrm{rpm}$ dan Frekuensi motor compresor dapat dihitung dengan menggunakan persamaan 1 .

$$
\begin{aligned}
n & =\frac{120 \times \mathrm{f}}{4} \\
f & =\frac{7620 \times 4}{120} \\
& =\frac{30480}{120} \\
& =254 \mathrm{~Hz}
\end{aligned}
$$

Dari hasil perhitungan diatas didapat nilai frekuensi motor compressor sebesar $254 \mathrm{~Hz}$ pada arus 12 Amper.

\subsubsection{Arus Compressor}

Untuk menghitung arus compresor, daya semu dan daya aktif yang digunakan harus dihitung terlebih dahulu.

Diketahui :

Pada Frekuensi 255 hz :

Untuk menghitung daya aktif pada motor compresor digunakan persamaan 2 .

$$
\begin{aligned}
\text { Daya aktif } & =\sqrt{3} \times V \times I \times \cos \varphi \\
& =\sqrt{3} \times 402 \times 12 \times 0,86 \\
& =7185,44 \text { Watt }
\end{aligned}
$$

Perhitungan arus motor compresor dengan menggunakaan persamaan 2 .

$$
\begin{aligned}
I & =\frac{P}{\sqrt{3} \times V \times \cos \varphi} \\
& =\frac{7185,44}{\sqrt{3} \times 402 \times 0,86} \\
& =\frac{7185,44}{598,78} \\
& =12 \mathrm{Amp}
\end{aligned}
$$

Dari perhitungan didapat arus motor compressor sebesar 12 Amper.

\subsubsection{Perubahan Kecepatan Compressor Akibat Perubahan Suhu di Luar Ruangan}

Pada saat suhu dalam ruangan telah tercapai dengan suhu yang direferensikan $24{ }^{\circ} \mathrm{C}$. Maka microcontroller akan menyesuaikan kecepatan compressor dengan cara merubah frekuensi dan tegangan inputnya. Penyesuaian tersebut dilakukan untuk menjaga suhu berada tetap dikisaran pada suhu referensi. Perubahan Suhu dari luar ruangan akan membuat kapasitas kalor juga ikut berubah, seperti pada Tabel 3. Dan untuk memastikan perubahan kecepatan akibat perubahan suhu diluar ruangan, seperti pada Gambar 7.

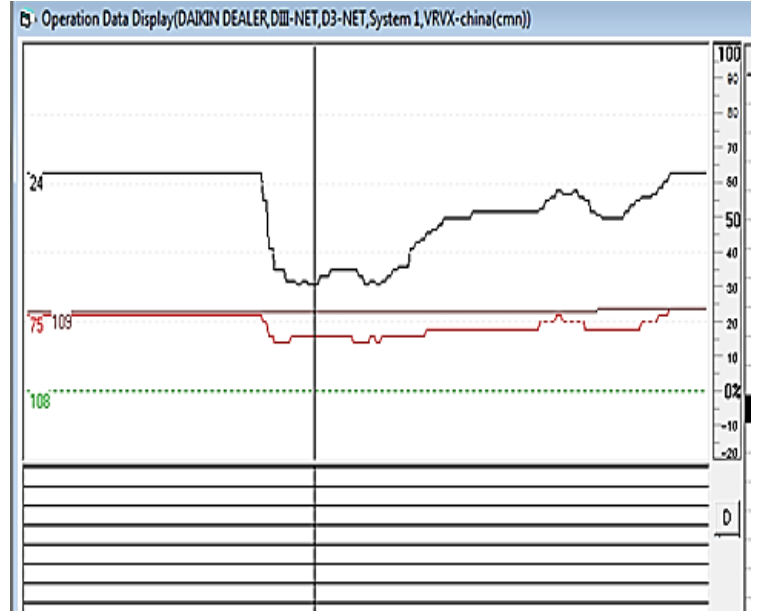

Gambar 7. Kecepatan motor compressor turun akibat perubahan suhu didalam ruangan.

Pada Tabel 3 menunjukkan, terjadinya penurunan suhu diluar ruangan. Dimulai dari jam 13.50 - 14.10 WIB. Penurunan suhu tersebut, juga membuat kecepatan motor compressor menjadi turun. Karena beban kalor dari luar ruangan turun yang membuat kapasitas pendinginan air conditioner juga ikut turun. Dari kecepatan 127 rps, turun bertahap sampai dengan kecepatan 65 rps. Dan akan naik kembali kecepatannya apabila terjadi kenaikan suhu dari luar ruangan.

Tabel 3 Data Hasil Simulasi Checker

\begin{tabular}{cccc}
\hline Jam & $\begin{array}{c}\text { Suhu indoor } \\
\left({ }^{\circ} \mathrm{C}\right)\end{array}$ & $\begin{array}{c}\text { Kecepatan } \\
\text { Compressor } \\
(\mathrm{rps})\end{array}$ & $\begin{array}{c}\text { Suhu } \\
\text { outdoor } \\
\left({ }^{\circ} \mathrm{C}\right)\end{array}$ \\
\hline 13:49:00 & 24 & 127 & 37 \\
$13: 49: 40$ & 24 & 111 & 37 \\
$13: 50: 40$ & 24 & 82 & 36 \\
$13: 51: 40$ & 24 & 71 & 36 \\
$13: 53: 20$ & 24 & 70 & 36 \\
$13: 53: 40$ & 24 & 65 & 35 \\
$14: 01: 20$ & 24 & 66 & 36 \\
$14: 09: 20$ & 24 & 64 & 35 \\
$14: 09: 40$ & 24 & 63 & 35 \\
$14: 10: 40$ & 24 & 65 & 35 \\
$14: 13: 20$ & 24 & 70 & 36 \\
$14: 16: 40$ & 24 & 86 & 36 \\
$14: 17: 40$ & 24 & 89 & 36 \\
$14: 18: 40$ & 24 & 92 & 36 \\
$14: 19: 00$ & 24 & 92 & 36 \\
\hline
\end{tabular}

Data pada Tabel 3 diambil dari record service checker pada jam 13:49 sampai 14:19 WIB. Pada saat jam tersebut kondisi suhu didalam ruangan sudah tercapai suhu referensinya yaitu $24{ }^{\circ} \mathrm{C}$, namun terjadi perubahan suhu diluar ruangan yang naik dan turun. Untuk menjaga suhu didalam ruangan tetap sesuai dengan suhu referensinya maka compressor akan meyesuaikan kecepatannya sesuai dengan perubahan suhu diluar ruangan. 


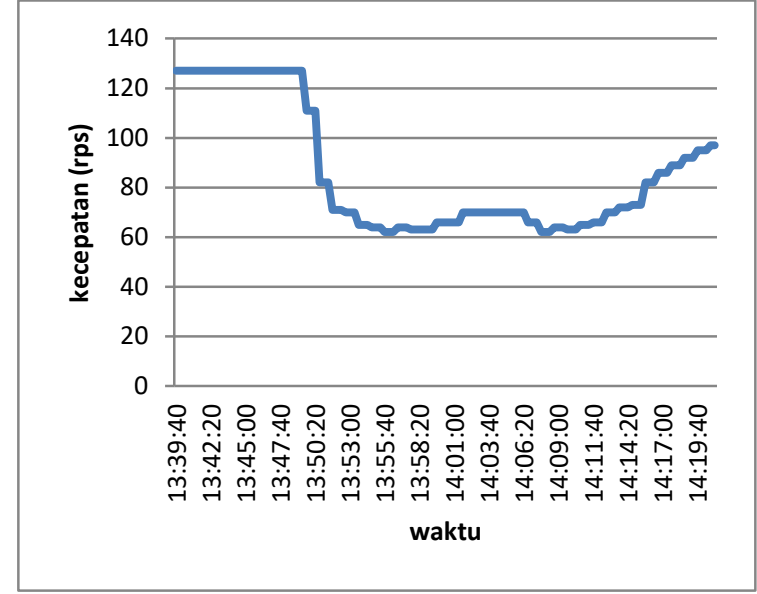

Gambar 8. Grafik Kecepatan Compressor yang Turun Akibat Suhu Outdoor.

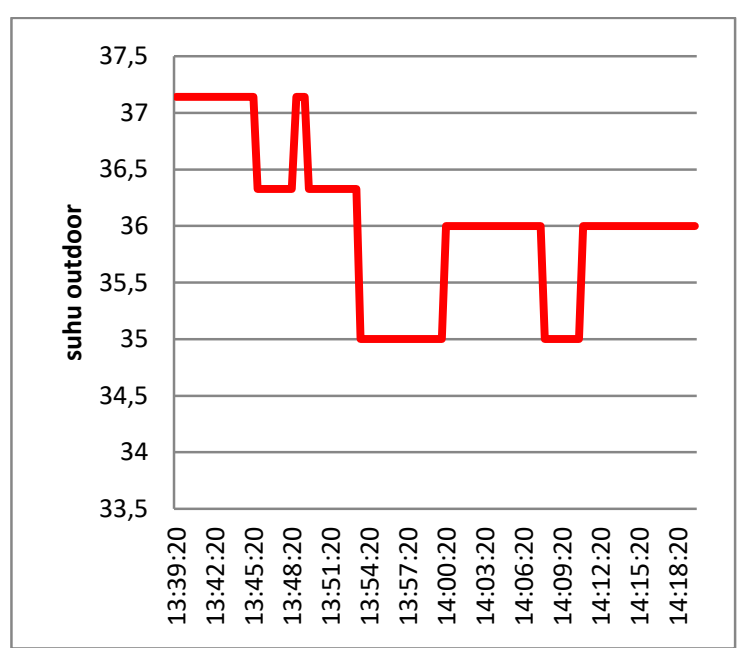

Gambar 9 Perubahan Suhu Outdoor yang Mempengaruhi Kecepatan Motor Compressor.

Pada Gambar 8 terjadi perubahan suhu diluar ruangan yang naik dan turun pada jam tertentu, membuat kecepatan motor compresor juga ikut berubah seperti pada Gambar 9. Mengikuti perubahan suhu diluar ruangan untuk menyesuaikan kapasitas beban pendinginan didalam ruangan yang sesuai dengan suhu referensinya yaitu $24^{\circ} \mathrm{C}$.

\subsubsection{Perubahan Kecepatan Compressor Mengikuti Perubahan Suhu Didalam Ruangan}

Suhu didalam ruangan terjadi perubahan karena pengaruh beban panas dari luar ruangan atau karena udara yang ada didalam ruangan keluar secara cepat melalui pintu ruangan saat membuka dan menutup pintu. Perubahan suhu tersebut akan membuat kecepatan pada motor compressor menjadi ikut berubah. Nilai perubahan suhu yang di ikuti oleh perubahan kecepatan motor compressor dapat dilihat pada Gambar 10.

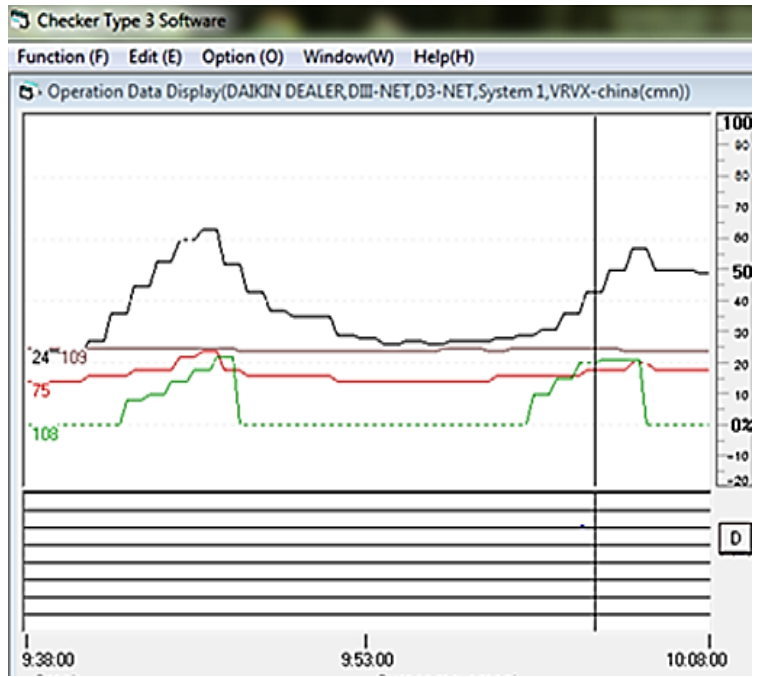

Gambar 10. Grafik Perubahan Suhu Didalam Ruangan dan Kecepatan Motor Compressor

Keterangan :

Garis hitam : Kecepatan motor compressor

Garis merah : Suhu dalam ruangan

Grafik hijau : Electronic Exspantion valve

Untuk menyesuaikan dari putaran motor compressor tersebut, elektronik exspansion valve akan menyesuaikan tekanan aliran refrigerant agar tetap sama. Pengaturan tekanan elektronik exspansion valve bertujuan untuk menghasilkan kapasitas pendinginan yang sesuai dengan kecepatan motor compressor. Untuk mengetahui nilai kecepatan, frekuensi dan tegangan input motor compressor dari beberapa titik suhu dapat di analisa dari Gambar 11 dan 12.

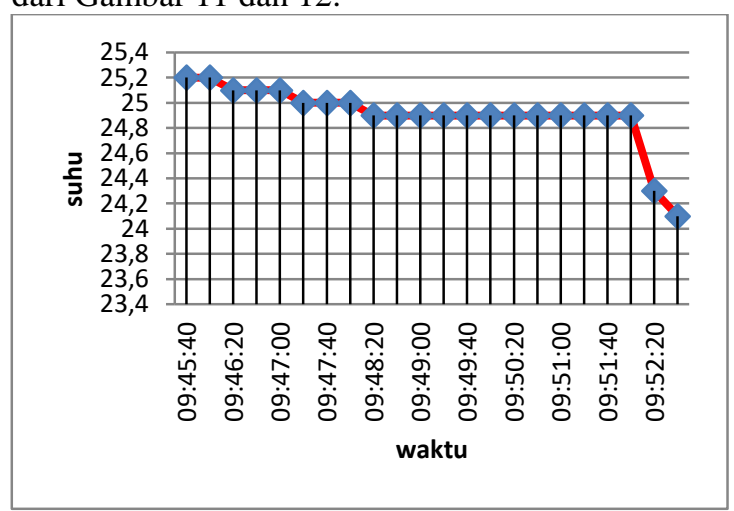

Gambar 11. Grafik Penurunan Suhu di dalam Ruangan yang Mendekati Setpoint.

Garis merah adalah nilai suhu dalam ruangan yang menunjukkan adanya penurunan suhu dari pukul 09.45-09.52 WIB (pemilihan jam tersebut diambil dari data checker saat penurunan suhu) adalah $25,2{ }^{\circ} \mathrm{C}-24,1^{\circ} \mathrm{C}$. Dengan adanya perubahan suhu tersebut, akan membuat putaran motor 
compressor juga ikut berubah turun. Karena settingan suhu yang diinginkan sudah tercapai. Perubahan kecepatan motor compressor seperti pada Gambar 12.

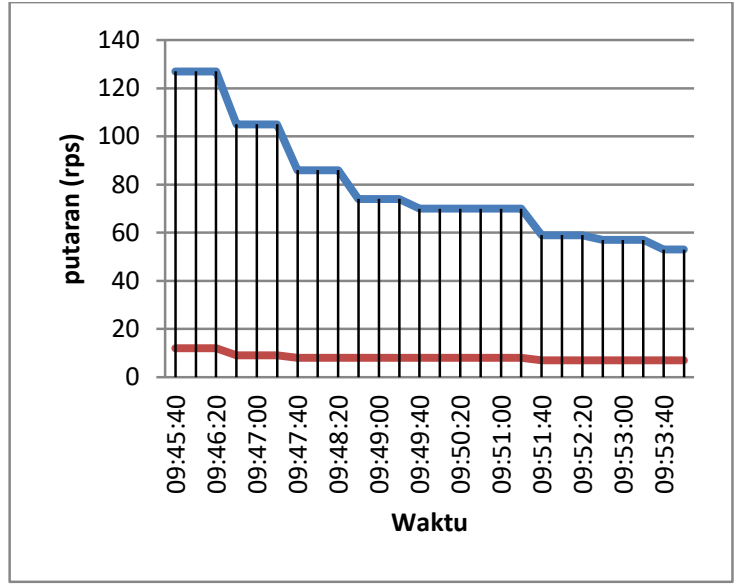

Gambar 12 Grafik Kecepatan Motor Compressor

Keterangan :

Garis biru : Kecepatan motor compressor dalam (rps)

Garis merah : Arus kerja motor compressor (Amp)

Perubahan suhu pada grafik Gambar 12, menunjukkan penurunan suhu yang turun sampai ke titik suhu referensi, saat suhu referensi sudah tercapai, maka microcontroller akan memerintahkan compressor juga perubahan kecepatannya menjadi turun. Perubahan kecepatan compressor dimulai dari 127 rps - 53 rps dan diikuti dengan arus kerja compressor yang juga ikut berubah. Semakin tinggi putaran motor, maka semakin tinggi arus kerja compressor dan sebaliknya.

Uraian dari analisa tiga buah titik suhu pada Gambar 12 :

1. Pada jam 09.45 WIB suhu dalam ruangan 25,2 ${ }^{\circ} \mathrm{C}$. Kecepatan motor compressor adalah 127 rps atau $7620 \mathrm{rpm}$ dengan arus kerja 12 Amper. Frekuensi $255 \mathrm{~Hz}$ dan tegangan input compressor $402 \mathrm{~V}$.

2. Pada jam 09.49 WIB suhu dalam ruangan 24,9

${ }^{\circ} \mathrm{C}$. Kecepatan motor compressor adalah $70 \mathrm{rps}$ atau $4200 \mathrm{rpm}$ dengan arus kerja 8 Amper. Frekuensi $123 \mathrm{~Hz}$ dan tegangan input compressor $271 \mathrm{~V}$.

3. Pada jam 09.54 WIB suhu dalam ruangan 24,1 ${ }^{\circ} \mathrm{C}$. Kecepatan motor compressor adalah 53 rps atau $3180 \mathrm{rpm}$ dengan arus kerja 7 Amper. Frekuensi $122 \mathrm{~Hz}$ dan tegangan input compressor $212 \mathrm{~V}$.

\section{KESIMPULAN}

1. Beban pendinginan air conditioner yang dibutuhkan untuk ruangan show room adalah sebesar 7,6 PK, dengan energy 69172,47 BTU pada saat suhu diluar ruangan $38,9^{\circ} \mathrm{C}$.

2. Putaran minimum dari compressor adalah 1560 rpm, dengan frekuensi input ke compressor 52 $\mathrm{Hz}$ dan tegangan input ke compressor sebesar 80 Volt dan pada putaran maksimum dari compressor adalah $7620 \mathrm{rpm}$, dengan frekuensi input compressor $255 \mathrm{~Hz}$ dan tegangan compressor sebesar 402 Volt.

3. Perubahan suhu didalam ruangan membuat kecepatan compressor menjadi turun, yaitu pada suhu $25,2{ }^{\circ} \mathrm{C}$ kecepatan motor compressor 127 rps / $7620 \mathrm{rpm}$, pada suhu $24,9^{\circ} \mathrm{C}$ kecepatan motor compressor $70 \mathrm{rps} / 4200 \mathrm{rpm}$ dan pada suhu $24,1^{\circ} \mathrm{C}$ kecepatan motor compressor 53 $\mathrm{rps} / 3180 \mathrm{rpm}$

\section{SARAN}

Pengaturan suhu didalam ruangan yang tepat sesuai kebutuhan dan kenyamanan tubuh menusia akan membuat efisiensi energi listrik yang lebih baik. Karena pada saat mengatur suhu diremot $A C$ dibawah $23{ }^{\circ} \mathrm{C}$, tubuh menusia tidak lagi nyaman beraktifitas dan $A C$ akan lebih lama beroperasi maksimal untuk mengejar target suhu yang diinginkan. Efeknya membuat beban listrik akan meningkat.

\section{DAFTAR PUSTAKA}

[1] Safitra, Ghani. 2013. Studi Variasi Beban Pendinginan Di Evaporator Low Stage Sistem Refrigerasi Cascade Menggunakan Heat Exchanger Tipe Concentric Tube Dengan Fluida Kerja Refrigeran Musicool-22 Di High Stage Dan R-404a Di Low Stage. Jurnal Teknik Mesin,Vol.II,No.1, ISSN No 23373539.

[2] Priyadi, Irnanda. 2009. Optimasi Penggunaan Air Contioner Sebagai Alat Pendingin Ruangan. Jurnal Ilmiah Bidang Sains, Vol.II,No.6, ISSN No 1978-8819.

[3] Priatna, Wahyu. Krishna. 2016. Perencanaan Ulang Sistem Pengkondisian Udara Pada Lantai 1 dan 2 Gedung Surabaya Suite Hotel di Surabaya, Jurnal Teknik Mesin,Vol.5, No.2, ISSN No 2337-3539.

[4] Trott, Weltc. 2000. Refrigeration and AirConditioning. Penerbit McGraw-Hill. India. ISBN 07506-4219. 
[5] Arismunandar, Wiranto. 1991. Penyegaran Udara. Penerbit PT.Pradnya Paramita. Jakarta. ISBN 979-409-038-1.

[6] Priowijanto, Gator. 2003. Dasar-Dasar Tata Udara, Modul Pembelajaran, Kode MK.RAD.01/04. Jakarta.

[7] Dossat, R.J. 1961. Principles Of Refrigeration. Penerbit Jhon Willey. New York.

[8] Handoko. 1961. Alat Control Mesin Pendingin. Penerbit Ichtiar Baru. Jakarta.

[9] M.Eppelheimer. 1997. ASHRAE Handbook Preface. Penerbit Frank M.Coda. Atlanta.
[10] Beaty, Kirtly. 2004. Electric Motor Handbook. Penerbit McGraw-Hill. New York.

[11] Zuhal. 2000. Dasar Teknik Tenaga Listrik dan Elektronika Daya. Penerbit PT. Gramedia Pustaka Utara. Jakarta.

[12] Rijono, Yon. 2004. Dasar Teknik Tenaga Listrik. Penerbit Andi. Yogyakarta.

[13] Gottlieb, Irving. 1997. Practical Electric Motor Handbook. Penerbit Boston. New Delhi. 